\title{
Assessing the Capital Efficiency of Healthcare Information Technologies Investments: An Econometric Perspective
}

\author{
Rodolphe Meyer 1,3, Patrice Degoulet ${ }^{2,3}$ \\ 'University Hospitals of Geneva, Geneva, Switzerland \\ ${ }^{2}$ Hôpital Européen Georges Pompidou and Université Paris Descartes, Paris, France \\ ${ }^{3}$ INSERM - UMRS 872 eq 20, Paris, France
}

\begin{abstract}
Summary
Objectives:To examine the different methods that can be used in the quantification of the added value of information technologies (IT) in the health care sector. This quantification represents a major issue for decision-makers and health care professionals when they have to plan an IT investment.

Methods: Articles were chosen via Medline, internet and the University of Geneva bibliographic portal. Some of the papers were obtained directly from their cuthors. We examine the most current methods used to evaluate IT return on investment (ROI) in the general business and in the health care sector, drawing attention on methods traditionally used in macroeconomic studies that could reveal themselves disruptive for IT ROl impact evaluation in hospitals.

Results: Financial and accounting methods can provide interesting data on a specific IT project but are usually incomplete for revealing the global IT investment influence. Econometric methods tend to demonstrate the positive impact of health care IT (HIT) on hospital production and productivity. Hospitals having higher levels of IT investment tend to deliver a higher level of clinical quality and show improved hospital cost performances.

Conclusions: Information technologies are so intermingled with people and processes that the identification of specific IT benefit remains questionable. Using macroeconomic tools could be the best way to analyze and compute IT ROl in health care. Econometric tools take into account all types investments (inputs) and all the returns (outputs) enabling the precise measurement of IT investments impact, breakeven points, and possible threshold levels, thus providing helpful intelligence to reach the higher levels of II governance in hospitals.
\end{abstract}

\section{Keywords}

Econometrics, return on investment (ROl), health care information technologies, HIT, production function, Cobb-Douglass, productivity

Geissbuhler A, Kulikowski C, editors. IMIA Yearbook of Medical Informatics 2008. Methods Inf Med 2008; 47 Supp 1:114-27

\section{Introduction}

Since the early seventies, information technologies in hospitals have acquired an ever increasing strategic and economic importance, particularly after studies highlight their possible role in improving the quality of care or reducing medical errors [1]. In the 21 st century, health information systems (HIS) have become so embedded in hospitals daily life that it has become almost impossible to make a decision without involving them [2]. But, even if everyone agrees on the importance of HIS, they remain these expenditure lines that did not brought full proof of their profitability, raising the recurrent problem of justifying the associated investments. The need to accurately quantify the added value of information technologies (IT) in the health care sector has therefore reached a critical requirement level.

On this basis taxonomies of evaluative methods have been proposed [3$6]$, and more and more studies have been published in the peer reviewed management and economic press, aiming to evaluate the economic impact of the ever growing IT importance in business. Unfortunately, few of them concern the health care sector and the financial benefits one could expect from IT in this field. "Use-user satisfaction" and "individual impact" rep- resent the majority of the assessments and according to Grover et al. [4], only $6.5 \%$ of evaluation studies are "costbenefit" types of analysis [7,8].

Numerous studies emphasize the indirect earnings (e.g., quality and continuity of care, users' satisfaction, process optimization, etc.) of implementing different components of a clinical information system (e.g., computerized physician order entry (CPOE), clinical decision support (CDSS), picture archiving and communications systems (PACS)) [2,9-14]. However, few studies in comparison have attempted to measure the direct earnings deriving from the integration of these different HIS components into a global portfolio or strategic approach. Furthermore, the contradictory results of these global studies frequently drive hospital managers to make decisions only on expected indirect benefits and some analysts have even declared that the very notion of healthcare information technology (HIT) return on investment (ROI) could be an oxymoron [15].

In this paper we will focus on the financial ROI approaches that have been published aiming to quantify the payback that could be expected from HIT deployment in health care. We will examine the different approaches, methods, and tools available to deciders and health care professionals. 


\section{Benefits from Health Infor- mation Systems (HIS)}

HIS can provide multiple benefits [2,9,10,16-18]. As shown in table 1, these benefits can fall into three categories: clinical, organizational and financial. Within these categories they can be tangible, meaning that their measurement is simple to compute, or less tangible meaning that, although obvious, they won't be easily quantified. All of these benefits are to be considered in a determine-the-valueof-the-HIS objective.

Financial benefits generally fall into one of the following categories: cost reduction, productivity improvement (which translates into cost reduction), revenue generation and competitive differentiation (which translates into revenue generation)

The return on investment (ROI), or sometimes rate of return (ROR), is the ratio of money gained or lost on an investment relative to the amount of money invested. The amount of money gained or lost may be referred to as interest, profit/loss, gain/loss, or net income/loss. The money invested may be referred to as the asset, capital, or the cost basis of the investment. ROI is also known as rate of profit. Return can also refer to the monetary amount of gain or loss. ROI is the return on a past or current investment, or the estimated return on a future investment. ROI does not indicate how long an investment is held. However, ROI is most often stated as an annual or annualized rate of return, and it is most often stated for a calendar or fiscal year. ROI is usually given as a percentage rather than an absolute value. This percentage can be used to compare returns on investments where the money gained or lost - or the money invested - is not easily compared using monetary val-

Table 1 Categories of Benefits in Health Care

\begin{tabular}{|c|c|c|c|}
\hline & Clinical & Organizational & Financial \\
\hline Tangible & $\begin{array}{l}\text { y latrogenic behavior } \\
\text { y Mortality \& Morbidity } \\
\text { y Information loss } \\
\text { > Drug deliverance }\end{array}$ & $\begin{array}{l}\text { y Transcription costs } \\
\text { y Supply \& Printing } \\
\text { y Length of stay } \\
\text { त Clinical paths }\end{array}$ & $\begin{array}{l}\boldsymbol{\lambda} \text { Revenues } \\
\boldsymbol{\pi} \text { Productivity } \\
\boldsymbol{\pi} \text { Reimbursement rate } \\
\boldsymbol{\pi} \text { ROI }\end{array}$ \\
\hline Less Tangible & $\begin{array}{l}\boldsymbol{\lambda} \text { Patient education } \\
\boldsymbol{\lambda} \text { Patient safety } \\
\boldsymbol{\lambda} \text { Standardization } \\
\boldsymbol{\lambda} \text { Clinical alignment }\end{array}$ & $\begin{array}{l}\boldsymbol{\lambda} \text { Coordination of care } \\
\boldsymbol{\lambda} \text { Information availability } \\
\boldsymbol{\lambda} \text { User satisfaction } \\
\boldsymbol{\lambda} \text { Organizational alignment }\end{array}$ & $\begin{array}{l}\boldsymbol{y} \text { Legal issues } \\
\boldsymbol{\lambda} \text { Business relationship } \\
\boldsymbol{\lambda} \text { Community image } \\
\boldsymbol{\lambda} \text { Financial alignment }\end{array}$ \\
\hline
\end{tabular}

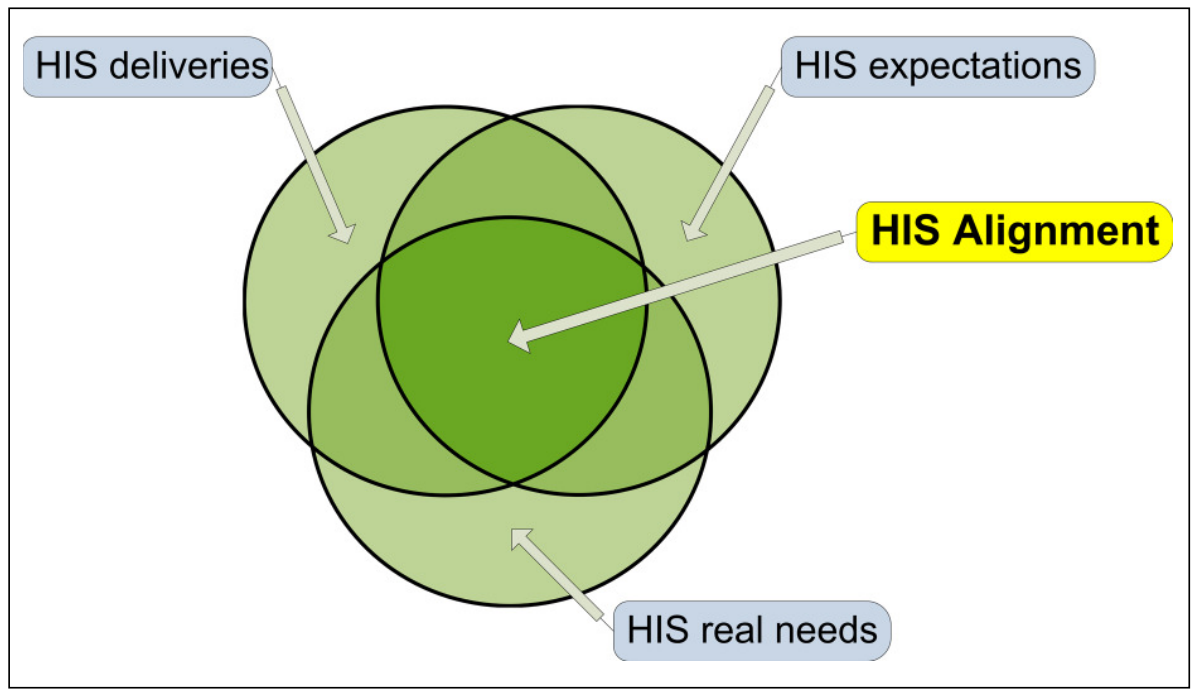

Fig. 1 HIS alignment

ues. For instance, a $\$ 1,000$ investment that earns $\$ 50$ in interest generates more cash than a $\$ 100$ investment that earns \$20 in interest, but the $\$ 100$ investment earns a higher return on investment $(\$ 50 / \$ 1,000=5 \%$ ROI vs. $\$ 20 / \$ 100=20 \%$ ROI)[19].

The duration in which the breakeven point (when investment equals return) is expected is another factor. Duration can indicate how much of the ROI is expected from the initial project release (for example, initial development) and how much is expected from the project's ongoing day-to-day maintenance and enhancements over a number of releases.

Particularly important is the notion of alignment payback. Align- ment payback is to be found in every aspect of the HIS and corresponds to a broader perspective of the hospital political and strategic value. Let's say that a good alignment could be represented by the level of evidence based medicine compliance of the clinical teams, by the implementation of international standards and right urbanization of the HIS and by the level of commitment in the community health politics or the economical aim the hospital. To sum up, alignment could be defined as the intersection of what people need, what they want and what they have (see figure 1). This is actually the ability of the system to deliver the results it was built for. 


\section{IT ROI Using Financial and Accounting Methods}

Many financial models exist to identify the ROI or try to estimate it more accurately. The most common methods are cost benefits analysis, net present value and the internal rate of return. They are mainly accounting methods and can be applied to almost every investment project of any kind.

\section{Cost Benefits Analysis (CBA)}

Cost benefits analysis correspond to the division of the total benefits given by a specific project divided by the amount of money used to build it. A ratio of 1.0 means that the benefits equal the invest-ments. A ratio of more than 1.0 indicates a positive ROI. As simple as it looks like, the data needed to perform such an analysis are far from simple to collect.

A recent and relevant study using CBA has been commissioned by the European Commission, Directorate General Information Society and Media, Brussels [11]. Ten European sites, with a wide range of different eHealth and healthcare settings (electronic health records (EHR), nation-wide medical record system, computerized physician order entry (CPOE) systems, clinical decision support system (CDSS), dispatch service for ambulance, supply chain management,...) were evaluated through a CBA that enables the impact on all stakeholders to be included in the evaluation. Cost-effectiveness (CEA) and cost minimization analyses (CMA) were not selected because they do not enable the evaluation of a range of outcomes. The authors estimated costs and timing of eHealth investment include recurring and non-recurring costs and benefits for each year including all beneficiaries (citizens, healthcare pros, third party payers, and others) in a way that full impact of eHealth could be revealed. All costs and benefits identified were computed and assigned a monetary value. The results obtained lead to conclude that all the ten European sites proved to have obtained positive economic impact from the deployment and utilization of their HIS. For most of them, these results seem to be obtained even after the first year of utilization [11].

Another interesting study using CBA was made in 2006 in the United States of America. Brigham and Women's Hospital CPOE Working Group (BWH is a 720 -adult bed, tertiary care, academic hospital in Boston) estimated costs and benefits of their hospital CPOE. Between 1993 and 2002, the BWH spent $\$ 11.8$ million to develop, implement, and operate CPOE. Over ten years, the system saved BWH $\$ 28.5$ million for cumulative net savings of $\$ 16.7$ million and net operating budget savings of $\$ 9.5$ million given the institutional $80 \%$ prospective reimbursement rate. The CPOE system elements that resulted in the greatest cumulative savings were renal dosing guidance, nursing time optimization, specific drug guidance, and adverse drug event prevention. The CPOE system at BWH has resulted in substantial savings, including operating budget savings, to the institution over ten years, but it took six years to reach the breakeven point [20].

\section{The Net Present Value (NPV)}

The NPV is the net result of a multiyear investment expressed in today's currency ( $€, \$, C H F$, $£$, etc.). In other words, it is the sum of the net benefits (net cash flows) over the life of a project, adjusting for the cost of capital [2]. NPV is an indicator of how much value an investment or project adds to the value of an enterprise. A positive NPV is necessary to acquire a specific technology because it suggests that incomes are greater than the present value of outcomes at a given interest rate (10). The key is to be exhaustive in identifying costs, benefits and their timing. NPV is especially appropriate for long-term projects. The main weakness is that ranking investments by NPV doesn't compare absolute levels of investment. NPV looks at cash flows, not at profits and losses the way accounting systems do. NPV is highly sensitive to the discount percentages that can be difficult to determine [21]. Few evaluations of HIT implementation using this technique have been published showing positive NPV [22,23]. A significant one, published by Rendina in 2000 showed that telecardiology, in addition to improving patient care was cost-effective in a neonatal deployment in the Washington DC area [24].

\section{The Internal Rate of Return (IRR)}

Closely related to the NPV, the IRR shows what return on investment can be expected as a percentage of the IT investment. It is the rate that makes NPV equals to zero for a series of future cash flows [2,10]. It's a cutoff rate of return: avoid an investment or project if its IRR is less than the cost of capital or the minimum desired rate of return. IRR provides a simple hurdle rate for investment decision-making. It's the method favored by many accountants and finance people even if not always easy to compute. For example computational anomalies can produce misleading results, particularly with regard to reinvestments [21].

\section{Risk Measuring Methods}

Investing in IT will always be associated with a certain level of risk. As- 
sessing these risks might require computer-aided complex calculations $[2,10]$ bringing a certain level of uncertainty based on their prospective nature.

Breakeven analyses try to estimate the break even period before positive cash flows equal the initial level of investments [25-27]. In other words: how long will it take to get the money back? The approach provides some indication of risk by separating long-term projects from short-term projects. On the other end, it doesn't measure profitability, doesn't account for the time value of money and ignores financial performance after the breakeven period [14].

Sensitivity analyses try to determine how the variation in the output of a model (numerical or otherwise) can be apportioned, qualitatively or quantitatively, to different sources of variation [28]. It can answer "what if..." questions on a variable by variable basis $[10,26]$. This analysis is more complex to implement than the precedent but can find out which variable in a model drives the results [29].

Scenario analyses examine possible future events by considering alternative possible outcomes (scenarios). The analysis is designed to allow improved decision-making by allowing more complete consideration of outcomes and their implications [27]. Despite the relative ease in understanding and run-ning a scenario analysis, the lack of no more than three (best, worst, and most likely) scenarios is limiting [10].

Monte Carlo simulation is a very popular technique to determine probable outcomes when adopting a new technology $[10,30]$. In a Monte Carlo simulation, random number generators reflect the probability distributions for variables of uncertain values are applied and run with variables of relatively certain values [26]. As the number of runs increases the certainty of addressing all possible financial outcomes is possible.
The weighted average cost of capital (WACC) is calculated using the organization's current or anticipated capital structure as the weighting factor. It incorporates the time value of money into the analysis. The WACC is calculated by adding the products of each project component's proportion or percentage of capital and its corresponding after-tax cost. As stressed by Holmes, "although widely used in financial decision making, it does not ensure an organization will be adequately rewarded for assuming risk" [31].

Real option reasoning is often described as a process heuristic for understanding the economics of sequential resource investment choices [32]. Thus, real options reasoning accommodates the value of flexibility, differing resource allocation horizons, the process of retrospective sense making, and path dependence [33]. This is a decision-like method that can be combined with scenario analysis. It has recently been presented and alleged to be adapted to the health care business [34].

\section{Data Mining and Regression Techniques}

A performance group analysis has been developed by Dr Menachemi's team at the Center on Patient Safety, Florida State University College of Medicine [35]. In their 2006 empirical study they examined the relationship between information technology utilization and hospital financial performance by specifying and testing a series of regression models. IT data come from the survey of 198 acute care hospitals in Florida and the complete financial report of the Florida Agency for Healthcare Administration (AHCA) for 2003. The performance group analysis concerns a set of operational performance indicators. To formalize hospital IT capabilities, they developed technology clusters by grouping individual IT applications. These applications were categorized as administrative, clinical, or strategic in nature. Each cluster was combined to form an index representing the count of actual IT applications in use for a given hospital under a given cluster [36]. Five indices (one for each of the clusters: administrative, clinical, strategic, patient safety and combined indices) were then computed with multiple linear regression analysis. Their findings suggest that IT adoption is consistently related to improved financial outcomes both overall and operationally. This relationship was present when examining clinical IT, administrative IT, and strategic IT as individual measures. Higher IT use was associated with a higher level of revenues, income, or cash flow, and was also associated with ratios based on higher expenses. Significant results were also obtained when considering IT collectively, the higher expenses certainly reflecting the relatively high acquisition costs associated with obtaining and maintaining sophisticated IT systems.

Data mining techniques have been used by a School of Information Technologies' team in Sydney Australia [37], assuming that data mining is a useful method of discovering meaningful new correlations, patterns and trends from large data warehouses. The data set comes from the Australian Bureau of Statistics (ABS) Business Longitudinal Survey (BLS) covering four consecutive years (1994 to 1998). The BLS was designed to provide information on the performance of Australian businesses and to identify various economic and structural characteristics of these businesses. It contains 3864 consistent records with a total of 787 variables having wide coverage of organizational characteristics and measures. They next 
applied two association rule network (ARN) techniques on their organizational variables. The first results seem to show that it is possible to visualize the potential interweaving of IT links among organizational practices. Furthermore this approach could provide evidence of the synergistic factors that affect performance positively or negatively allowing defining coinvestments patterns policies [37].

\section{Corporate Methods}

Several consulting firms have developed their own IT ROI metrics, methodologies, guidelines and benchmarking. Examples include the Economic Value Added (EVA) by Stern Stewart \& Co [38], the Business Value Index by The Hackett Group [39], the Balanced Scorecards by Palladium [40], the Information Economics methodology by The Beta Group [41], the IT Performance Management Group (ITPMG) method [42], the Total Economic Impact by Forrester Research [43], and the Total Value of Opportunity by Gartner Inc. [44].

\section{Where Accounting and Economic ROI Methods Fail}

By their very nature financial/economic tools do not reveal the less intangible impacts of IT investments such as the possible increased employee productivity or customer satisfaction [9]. They also have the hazardous tendency to underestimate some IT capital "real world" aspects. An example could be given by the frequent underestimation of the IT capital knowing that PC and mainframes are frequently used past their accounting depreciation life, impairing the results of the studies where the IT hardware value is aggregated.
ROI models might fail when they become overly complex. As says Stephen Andriole, an MIS professor at Villanova University in Villanova, PA., there are roughly 15 financial calculations that CIOs can use to tally ROI, "and that's part of the problem -- the more complicated the method, the more you have to feed the method rather than working the project". IT leaders "should adopt what the business adopts, and that's fine if that's how the organization wants to view the numbers", says Audrey Apfel, an analyst at Gartner Inc. in Stamford, Conn [44]. Unfortunately, this is not relevant in health care. "The problem with relying solely upon financial techniques such as NPV or IRR is that they don't necessarily capture all of the business benefits of an IT investment" respond Chip Gliedman, an analyst at Giga Information Group Inc. Giga recommends that CIOs use options models, decision trees and other tools [45].

Isolating and trying to measure the value added by a single project, like a PACS acquisition and deployment, is akin to assessing the contributed value of the cheese to the pizza. As Steve Ulfelder stressed in Computerworld columns "the idea that there are IT projects must be abandoned. There are only projects targeted at improving business processes, developing new products or services, delivering more efficient customer service or improving some other aspect of business performance" [46]. On a further level all the financial tools described before, when they are used to evaluate a future investment, tend to be systematically biased against innovation. Or as Christensen said in the January 2008 Harvard Business Review about their exclusive use "they divert resources away from investments whose payoff lies beyond the immediate horizon" [47].

\section{An Econometric Approach to ROI Measurement}

Econometrics is concerned with the tasks of developing and applying quantitative or statistical methods to the study and elucidation of economic principles. Econometrics combines economic theory with statistics to analyze and test economic relationships. Theoretical econometrics considers questions about the statistical properties of estimators and tests, while applied econometrics is concerned with the assessment of economic theories [48,49]. Macroeconomic theory examine economy-wide phenomena such as changes in unemployment, national income, rate of growth, gross domestic product, inflation and price levels. It is possible to narrow its mechanisms and make a focus reaching a firm or sector level. This focusing is provided by the microeconomic theory (or price theory) that is a branch of economics that studies how individuals, households, and firms make decisions to allocate limited resources, typically in markets where goods or services are being bought and sold. Microeconomics examines how these decisions and behaviors affect the supply and demand for goods and services, that determines prices, and how prices, in turn, determine the supply and demand of goods and services. Firms providing these goods and service are organized capitalistic structures possessing their own level of efficiency in their market.

In the previous chapters we saw that an approach commonly used to measure capital efficiency is given by the returns on investment. The economic approach of capital efficiency is generally represented by the informal ratio of production divided by capital expenditure [50]. The larger the ratio, the better capital efficiency is, thus leading to greater output [51-53]. In the 
econometric field, sensitive data on this efficiency are provided by the utilization of production or cost function.

\section{Production or Cost Functions}

Since the 19th century, it has been common to link the growth and productivity of an enterprise to the elements, or production factors, used to generate products or services. The explanation of the economic growth by the combination of production factors led to the notion of production function, a mathematical relationship established between the production (output) and the factors put together to obtain it (inputs). A major step in this field was achieved by the American economist Paul Douglas and the mathematician Richard Cobb [54], who proposed a non-linear function linking yearn (Y), capital (K) and labor (L). The initial studies with this function undertaken in 1930 particularly concerned the industrial sector, and since then have spread to all economic sectors seeking efficiency. In 1956, Robert Solow [55] enhanced the function by introducing a new factor known as the Solow residual that is related to the technology level. The production function can then be expressed as:

$$
\mathrm{Y}=\mathrm{A} \cdot \mathrm{K}^{\alpha} \cdot \mathrm{L}^{\beta}<1>
$$

where $\mathrm{Y}$ will represent the output, A is the Solow residual, $\mathrm{K}$ the capital stock and $\mathrm{L}$ the quantity of labor brought back to its monetary value. Alpha and beta are called elasticity coefficients. They represent the share of each input explaining the output $\mathrm{Y}$ (let's say that $\mathrm{x} \%$ raise of $\mathrm{K}$ will give an alpha\% raise of the incomes). The classical Cobb-Douglas will assume the constant elasticity of substitution of the inputs (i.e., $\alpha+\beta$ $=1$ ) an assumption that economists also call constant return to scale [55].
Using the mathematical properties of the function it is possible to add a third variable to the classical Cobb-Douglas function called $\mathrm{T}$ [56]. This variable represents the share of IT that is involved in the incomes produced, by withdrawing IT labor from Labor and IT capital from capital. Merging the IT Labor and IT capital we get the T variable and its elasticity coefficient $\gamma$.

$$
\mathrm{Y}=\mathrm{A} \cdot \mathrm{K}^{\alpha} \cdot \mathrm{L}^{\beta} \cdot \mathrm{T}^{\gamma}<2>
$$

As in the classical Cobb-Douglass function it's possible to assume the constant elasticity of substitution of the inputs (i.e., $\alpha+\beta+\gamma=1$ ). Knowing the value of the output $(\mathrm{Y})$ and of the inputs $(\mathrm{K}, \mathrm{L}$ and $\mathrm{T})$, the value of the $\alpha, \beta$ and $\gamma$ elasticity factors can be calculated to estimate the importance of each input in the explanation of the observed output [57].

\section{Econometrics for IT ROI in the General Economy}

In 1990 Alpar \& Kim [58] found that methods using tools based on the production theory from economics could provide insights that were not obvious when more loosely controlled statistical analyses were performed [59]. The first study regarding IT impact on production, using these kinds of tools, or close ones, is found in 1992 [60] using hierarchic regressions. Since then other econometrics methods have been used including productivity factors correlations [61], Pearsonian or canonic correlation [62], regression analysis $[63,64]$, production and Cobb-Douglas functions [56,65-71].

All the authors didn't reach the level of certainty that could have proved the positive impact of IT investments in the industry and business area. Even worse, some of them found that there was no positive correlation overall between IT investments and production $[65,72,73]$ or that computer investments are not significantly correlated with increases in return on assets [72,74]. These results led to what has been called the IT productivity paradox.

The IT productivity paradox is a situation where it's possible to see an immediate reduction of the tangible financial benefits of a firm just after the deployment of a complex Information System [75-78], leading to question the very notion of IT interest in productivity. Since the nineties, this IT productivity paradox engendered an increased scientific interest causing a significant amount of research pioneered at the Wharton School of the University of Pennsylvania and the Sloan School of Management at MIT by Lorin Hitt and Erik Brynjolfsson [79].

In 1996, Studying 370 corporations from 1988 to 1992, Hitt and Brynjolfsson found that, during this period, IT in these firms had increased productivity and created substantial value for consumers. However, they discovered that these benefits had not resulted in major business profitability. Finally they concluded that while modeling techniques need to be improved, the results were consistent with economic theory and that there is no inherent contradiction between IT investments and increased productivity, increased consumer value and unchanged business profitability. Hitt and Brynjolfsson won the award for "best paper for 1996" in MIS Quarterly a peer reviewed scholarly refereed journal in the information systems field.

They opened the way to many other studies that used econometrics techniques to show (in chronological order) that:

- IT labor was productive in the retail banking sector between 1993 and 1995 [80];

- IT capital is more important for the 
services industry than for the manufacturing industries, and IT stock, capital and labor are not pairwise substitutable [81];

- IT capital in general business is linked to labor and capital in productivity gains $[82,83]$;

- USA computer assisted firms from 1988 to 1993 have had higher productivity [68];

- A positive relationship exists between IT investments and labor productivity in the Canadian and US industry from 1971 to 1993 [70];

- IT had a noticeable positive impact in all industrial sectors of US economy between 1959 and 1998 [71], especially on productivity between 1991 and 1994 [84] leading to suspect a time threshold;

- Successful IT investments brought higher financial performances in 71 firms between 1988 and 1997 [85];

- $\quad$ IT investments improved technical efficiency, productivity and incomes in 370 business firms in the USA between 1988 and 1992 [86-90].

All this research required considerable effort and analysis from many authors. They all center their attention on industry and services in general, concluding that there may be a temporary productivity paradox when investing in IT but that all the firms who crossed the chasm proved to have made a right economic decision. None of these studies, however, focus especially on health care which could prove problematic regarding the specific nature of this sector of economic activity.

\section{Health Care IT ROI with Econometric Analyses}

Econometric models applied to hospitals must be adapted in order to integrate health care specificities. Economic studies in the medical information domain raised theoretical and practical issues such as the definition and measurement of hospital production, efficiency or productivity [9193]. Yet, it is essential in the health domain to be able to estimate the benefits of technology investments on hospital activities.

The first econometric approach of the health care sector was made in the businesses school of three US universities in 2000 (Texas Tech University, College of Business; the University of Illinois at Chicago, College of Business, and the University of Arizona, Karl Eller School of Management). Nirup Menon, Byungtae Lee and Leslie Eldenburg analyzed the impact of IT in a healthcare setting using a longitudinal sample of hospital data from 1976 to 1994 [94]. Data for the study were obtained from the Washington State Department of Health, the dataset (1130 observations) excluded any specialized hospitals such as psychiatric and substance abuse treatment centers. They classified production inputs into labor and capital categories. Capital was classified into three components - medical IT capital, medical capital, and IT capital - and labor was classified into two components, medical labor and IT labor. They used a state-of-the-art parametric technique, the stochastic frontier approach. Since this approach assumes all production processes are inherently inefficient, the model parameters capture inefficiencies of the production process at the firm level [95] (this approach models the production process for each hospital more realistically). Results obtained with that methodology provided evidence that IT contributes positively to the production of services (outputs) in the healthcare industry. IT labor and medical labor exhibited a positive influence on output as well as a positive impact on mean marginal revenue. However, they found that medical capital appeared to be negatively associated with output during this time period. To quote these authors "...this finding may reflect hospitals' attempts to contain costs by substituting outpatient services for inpatient services, resulting in a decrease in length of stay for acute care wards (where medical capital is invested) and increasing outpatient visits for diagnostic tests and procedures (where medical IT capital is invested)..."[94]

In 2003, Myung Ko and KwekuMuata Osei-Bryson explored the productivity impact of information technology (IT) in the healthcare industry using a regression spline (RS)-based approach on production function [90]. They used the same dataset as Menon and Lee [94]. Their analysis was based on a translog production function enabling the possibility of exploring the interactions between the predictor variables (non-IT Capital; non-IT Labor; and IT Stock). The use of multivariate adaptative regression splines (MARS) allowed them to understand the complex relationship between IT investments and productivity in the healthcare industry [96]. The rather complex results of this study suggest that each input variable has an interaction with other input variables. The results also suggest that under certain conditions, investments in IT stock have a positive impact on productivity, and that this impact of IT is not uniform but is conditioned both by the amount invested in the IT stock and the investments in non-IT capital. Thus, identifying an optimum level of the investment in each variable, may lead to higher productivity at the hospital level.

With such precedents, in 2006 we carried out an econometric analysis of 17 not-for-profit hospitals in Paris [16]. The study had multiple goals: to show that a classic econometric production function is adaptable to French not-for-profit hospitals, - to compute 
and analyze the share of each input variable in the explanation of the measured hospitals outputs and evaluated the production impact of IT investments, - and to compare the share of IT in the production results between two sets of hospitals split on an IT integration level basis.

The study concerns 17 of the 38 Paris university hospitals within Assistance Publique Hôpitaux de Paris (AP-HP). These hospitals were selected according to their size (more than 350 beds) and activity (acute and short-term care). Data used in this study range from 1998 to 2005 . The 17 hospitals were split into two groups according to their IT integration level. Group 1 consisted of 11 hospitals having mainly administrative and ancillary department management systems (i.e., laboratory, radiology and pharmacy). Group 2 consisted of 6 hospitals that installed or had started to install an integrated HIS during the study period (first one in 1998, second one in 2000, the others throughout 2003). Using an aggregate Cobb-Douglas function [48,57] the links between hospital production and three different inputs (capital stock, quantity of labor, information technologies) were evaluated assuming the constant elasticity of substitution of the inputs [55]. The results showed that it is relevant to use econometric analysis tools in not-forprofit hospitals. In addition, with a share of labor in the hospitals superior to what is generally admitted in the industrial or service sector in France, the elements brought by the Cobb-Douglas production function stressed the importance of the human factor in explaining the hospitals' production results (Table 2 ).

The results seemed also to confirm the positive impact of IT on the studied hospital production during an eight-year period of follow-up. Comparing the two groups, the computation tends to reveal that the share of IT explaining the pro-

Table 2 Inputs factors coefficient values in different studies. Adapted from: Meyer R, Degoulet P and Omnes L. Impact of Health Care Information Technology on Hospital Productivity Growth: a Survey in 17 Acute University Hospitals. Medinfo 2007; 12(1):203-7.

\begin{tabular}{|lcccc|}
\hline Studies & $\mathbf{a}$ & $\boldsymbol{B}$ & $\boldsymbol{\gamma}$ & $\mathbf{R}^{2}$ \\
\hline Hitt-1996 [56] & 0.2280 & 0.6860 & 0.0307 & 0.9510 \\
Hitt-1999 [97] & 0.1300 & 0.7300 & 0.1100 & 0.9400 \\
Lin - 2000 [98] & 0.1240 & 0.7890 & 0.1600 & 0.9750 \\
Shao-2001[89] & 0.2121 & 0.7040 & 0.0619 & n.a. \\
Bresnahan - 2002 [99] & 0.1380 & 0.7530 & 0.0347 & 0.9080 \\
Osei-Brison - 2004[90] & 0.2120 & 0.6630 & 0.0883 & 0.9700 \\
Meyer-Degoulet-2007 [16] & 0.1686 & 0.7657 & 0.0853 & 0.9701 \\
\hline
\end{tabular}

a $=$ share of capital, $\beta=$ share of labor, $\gamma=$ share of IT

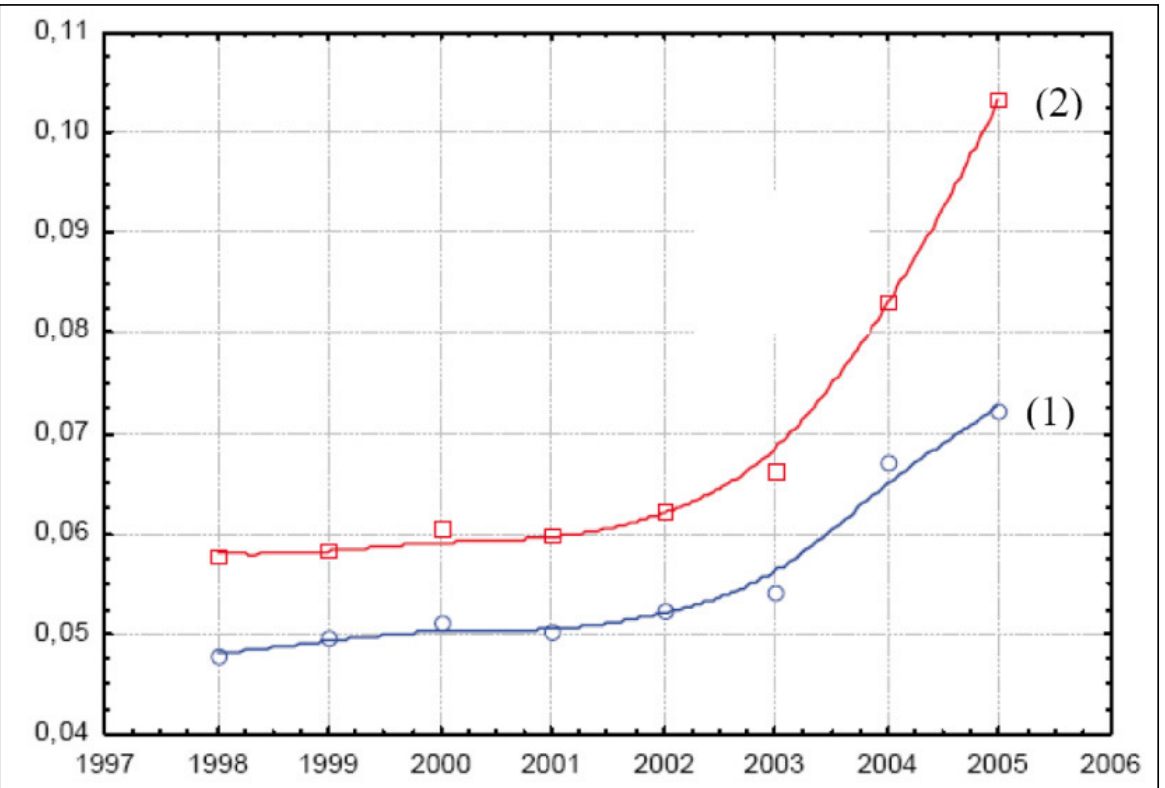

Fig. 2 importance of IT share between high level HIS integration hospitals [2] and low level ones [1]. From: Meyer R, Degoulet P and Omnes L. Impact of Health Care Information Technology on Hospital Productivity Growth: a Survey in 17 Acute University Hospitals. Medinfo 2007; 12(1):203-7.

duction observed is about 1.7 times more important in structures having a higher level of CIS integration than in the lowlevel ones; this tendency increasing over time as shown in the figure 2.

In 2007, PricewaterhouseCoopers (PwC) and researchers at the Wharton School of the University of Pennsylvania released a major macroeconomic analysis of costs and quality of US hospitals aiming to investigate healthcare IT investment effects [100]. The twofold objective was to confirm the rela- tionships between IT investments and other measures of hospital performance by using advanced statistical and econometric techniques; and also, to establish whether such relationships support the assertion that investment in IT by US hospitals actually enhances organizational performance. They collected the data of almost all US hospitals (around 6000) over a period ranging from 1999 to 2004. After excluding psychiatric hospitals, government hospitals, hospices, rehabilitative and 
chronic care facilities, very small hospitals (under 50 beds) and inconsistent dataset from their panel they ended up with almost 2000 structures. The resulting sample population was further divided into for profit and not for profit hospitals. To analyze the huge ensuing database they used standard econometric tools and powerful statistical techniques. This gave birth to a cost function, rather than a production function as used in the other studies. This economic model inter relates hospital capital infrastructure costs, operating expenses, outputs, material costs, labor costs, IT investment, and few other factors. Higher levels of IT investment correlate with improved hospital cost performance, although sometimes only modestly, and this amelioration increase over time. IT investments in acute care hospitals are associated with reduced operating expenses, but only after hospitals have reached a threshold level of investment. In other words, the initial stages of IT acquisition are, in fact, costadditive until a "critical mass" is achieved, at which point the relationship becomes neutral for a period of time but ultimately turns positive. Another interesting result is that there is a natural lag time between technology implementation and benefits realization. Cost reductions occurred in the same year as the IT acquisition, but generally it took two years to break even.

This two year time lag can be visualized in figure 3 where each year's hospital performance statistics is related with IT Capital Index values from one and two years earlier. As a result it shows that the cost reductions associated with IT appeared at lower levels of IT investment, when this time lag is taken into account. No other effects of introducing the lag were observed. Not-forprofit hospitals appear to experience smaller cost-reduction effects when implementing HIS than for-profit hos- pitals and reach their tipping point at higher levels of IT capital [100].

Hospitals having higher levels of IT investment tend to have a lower mortality rate (adjusted for risk and case mix) (figure 4). The effect is independent of costs per bed. The mortality rate may not represent the gold standard of quality level, but as N. Beard said "mortality is accepted as being a part of a stable of measures that together may form a reasonable guide to quality of care" [100]; so the finding that IT investment could correlate with a lower mortality rate is directionally encouraging [101].

\section{Discussion and Conclusion}

Although the literature includes encouraging findings, more research is needed to extend the understanding of the relationship between IT investment and financial outcomes on a macroeconomic level. Some points in the analysis remain to be developed. First of all, investigation should precise the duration of the lag period existing between the first investment and the breakeven point. Some studies relate a five years or more lag [20], others have measured a two years lag [100], while few report

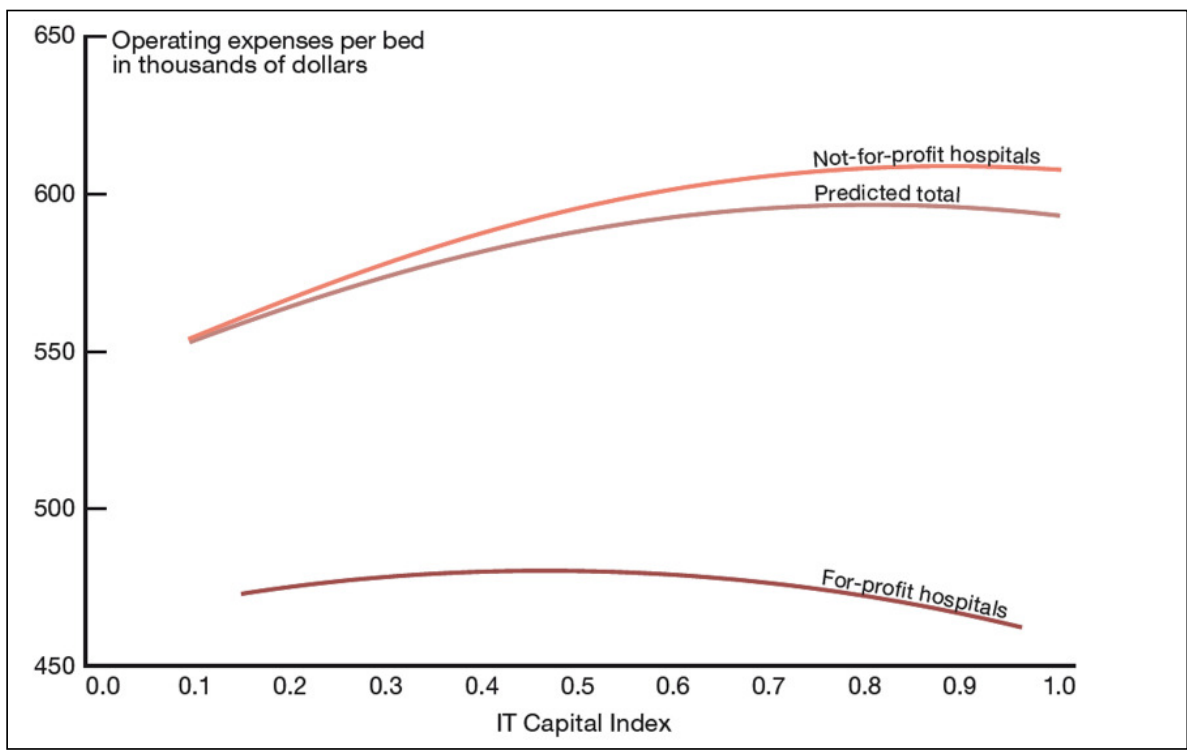

Fig. 3 Effect of Two-Year Lagged IT Capital Index on Operating Costs per Bed. From: Beard N, et al. Informa-tion technology and hospital performance: an econometric analysis of costs and quality. PricewaterhouseCoopers 2007 (http://www.pwc.com/healthcare).

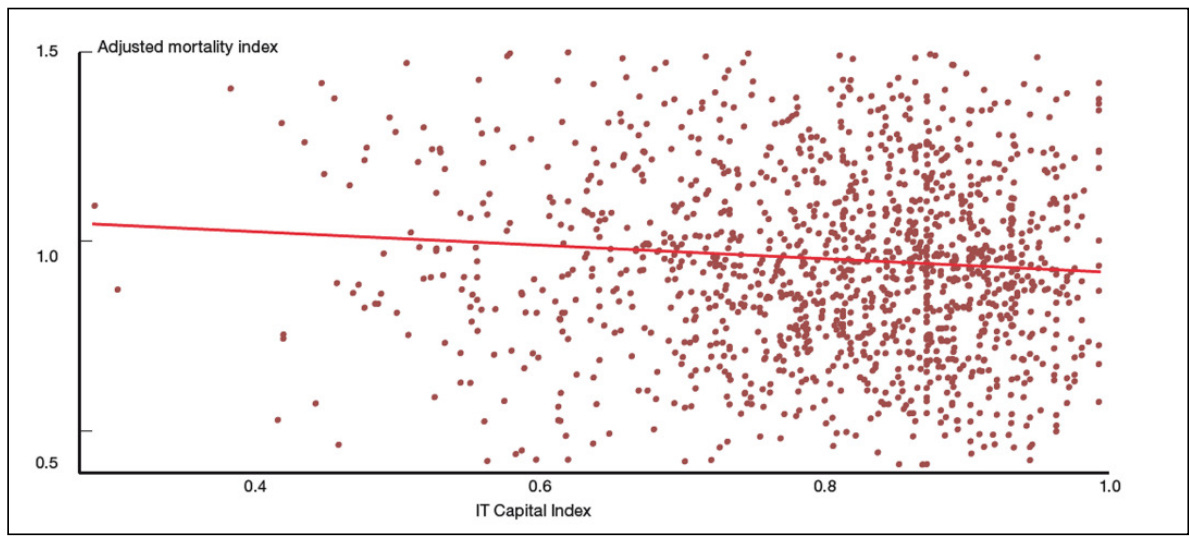

Fig. 4 Adjusted Mortality by IT Capital Index, 2004. From: Beard N, et al. Information technology and hospital performance: an econometric analysis of costs and quality. PricewaterhouseCoopers 2007 (http://www. pwc.com/healthcare). 
a positive ROI the same year of the deployment [10]. In our experience, it takes about two to three years to start to deploy a reliable partial or complete HIS, and it take additional time (one or two years) to reach a satisfying "cruise altitude" fulfilling its' alignment objectives. Future econometric studies should incorporate this lag time in their computation.

In the various econometric works (in general economy and in health care sector) IT variables taken into account were constructed in a way that can raise questions. Most of the studies aggregated the IT labor with the IT capital. This is an interesting approach, but the granularity of the variables studied could be widened examining IT labor and capital separately or by splitting general labor into IT labor, medical labor and non medical labor, etc. The mathematical properties of the production function allow these extensions. Even the very notion of IT capital could be discussed. Indeed, in a hospital possessing a very high level of integration, the capital used to buy a new PET-Scan could be assigned to IT, considering the apparatus as merely a new networked image producing device, a situation that may be less relevant in a lower level IT structure. Studies incorporating this concept should be done. This more detailed specification of variables would be a first step towards better understanding the intricate relationships that can exist among them at the time of investment. Furthermore, benefits associated with HIT appear to be higher when accompanied by coherent clinical process redesign. This process redesign level could represent an interesting variable to examine comparing institutions that have and others that didn't make this effort $[2,100,101]$.

The correct identification of hospitals will be also a point to develop. Studies can no longer aggregate for profit and not for profit hospitals. And in these two groups it's important to determine categories of structure pursuing the same health care objectives. The best results of single institutions case studies cannot provide the sufficient level of confidence needed by investors to sign up in an ambitious HIT project. On this base the extension of the studies, actually mainly concerning the USA, should be done into other HIT involved countries on the same level.

In this review we have shown that there is no longer a scarcity of studies demonstrating the added value of IT in healthcare, despite recurrent assertions to the contrary. Much progress has been made in this field as reported in a large scientific peer reviewed literature. The majority of contributions point to positive results from various HIS implementations even though conceptual and methodological issues remain $[2,21,35$, $47,100,102]$. Information technologies are a composite mix of hardware, software, knowledge, integration level, operational support and infrastructures. Too many studies analyze the impact of single IT projects in a period where it has been shown that the real HIS ROI can more definitely be obtained with the implementation of highly integrated systems [16,100]. Doing so these hospitals are investing significant time and effort in complex measurement processes to attempt to track returns. Some are now beginning to question the value of the exercise. In many cases, information technology is so inextricably intertwined with people and processes that the identification of specific technology-related benefit streams is of marginal value [1]. Moreover, the financial tolls used by experts didn't proved to be perfectly accurate and many of the methodologies used possess inherent approximations and economic postulates that raise sometimes more questions than answers $[2,5,7$,
$10,45-47,103]$. Productivity is arguably the single most-important economic statistic. Its corollary the return on investment produces the golden numbers on which every future investment decision will be decided; thus the importance of finding the closest to reality results. Pursuing this objective this review paper suggests that new economic approaches derived from macroeconomic considerations and based on econometric tools could prove more reliable in assessing the real value of portfolio IT ROI and especially in the health care domain $[16,90,94,100]$. All these recent studies made in the health care business assessed the positive impact of HIS; an impact with a fast ROI and sustained over time.

The first statement about advocating the necessity of using macroeconomic tools is that when using traditional financial tools, experts always measure the do-nothing scenario, against which cash flows from the investments are to be compared, assuming that the present health of the hospital will persist indefinitely into the future if the investment is not made. This could constitute a sort of mistake that we call the entropy fallacy, because experts analyses always presume that the entropy of their system won't rise in their predictive financial data computing, which is wrong. And to go even further, a given hospital situation could be worse off than it is now after having made an IT investment but better off than he would have been without it [35]. Keeping that in mind when brainstorming about the relevance of doing an investment could save time/money, and cope with a recommendation saying that hospital executives should not justify expensive new IT investments solely on the assumption that these investments will deliver large returns. A more effective approach may be to justify moving along the curve to a position where 
future IT investments pay for themselves and at the same time position the hospital for long term quality improvements [100].

A major conclusion could be that in advanced economies, IT is a promising source of productivity growth, but it makes little direct contribution to the overall performance of a company or the economy until it is combined with complementary investments in work practices, human capital, and organizational restructuring $[104,105]$. ROI evaluation of HIS impact in hospitals must climb a step up and match the total investments (inputs) with the total of returns (outputs) regardless of the source of each of them. Organizational contextual variables are important factors to consider in determining the impact of IT investment on organizational performance [106-110] but can remain very hard to be financially quantified, potentially impairing the results of desired deep analysis. Only a strategic alignment level analysis can be relevant in the HIS actual case as long as we have now identified that quantitative analyses based on production function are considered theoretically rigorous [111,112]. From the perspective of a general scheme of incentives and sustainability, it could be said that health care is moving from evidencebased medicine to economic-based medicine (using evidence of cost effectiveness) [113]. While econometric analysis may not become a "unified theory" for HIS, econometric tools do provide helpful intelligence for raising the level of IT governance in hospitals.

\section{References}

1. Kohn LT, Corrigan JM, Donaldson MS, editors. To Err Is Human: Building a Safer HealthSystem. Institute of Medicine. Washington DC: National Academy Press; 1999.

2. Arlotto P, Oakes J. Return on investment: maximizing the value of healthcare information technology. Chicago: HIMMS; 2003.

3. Delone WH, McLean ER. Information Systems Success: The Quest forDependent Variable. Information Systems Research 1992;3(1):60-95.

4. Grover V, Jeong SR, Segars AH. Information system effectiveness: the construct pace and patterns of application. Information and Management 1996; 31(4):117-91.

5. Van der Loo RP, Van Gennip EMSJ, Baker AR. Evaluation of automated information systems in health care: an approach to classifying evaluative studies. Comput Methods Programs Biomed 1995;48(1):45-52.

6. Brennan A, Chick S, Davies R. A taxonomy of model structures for economic evaluation of health technologies. Health Econ 2006;15:1295-310.

7. Pekka T, Hannu S. The Economic evaluation of Medical Information Systems. A research paper presented at the 18th Nordic Health Economists' Study Group Meeting. 22-23 August, 1997, p. 21.

8. Gardner RM, Hulse RK, Larsen KG. Assessing the effectiveness of a computerized pharmacy system. Symposium on Computer Applications in Medical Care; 1990, Vol. 14. p. 668-72

9. Menachemi N, Saunders C, Chukmaitov A, Brooks R. Hospital quality of care: Does information technology matter? The relationship between information technology adoption and quality of care. Health Care Manage Rev 2008;33(1):51-9.

10. Menachemi N, Brooks RG. Exploring the return on investment associated with health information technologies. Florida State University College of Medecine: Center for Patient Safety; 2005.

11. Stroetmann KA, Jones T, Dobrev A, Stroetmann VN. eHealth is worth it: the economic benefits of implemented eHealth solutions at ten European sites. Luxembourg: Office for Official Publication of the European Communities; 2006.

12. Barlow S, Johnson J, Steck J. The economic effect of implementing an EMR in an outpatient clinical setting. J Healthc Inf Manag 2004;18(1):46-51.

13. Cooper J. Organization, Management, Implementation and Value of EHR Implementation in a Solo Pediatric Practice. J Healthc Inf Manag 2004;18, (3):51-5.

14. Wang SJ, Middleton B, Prosser LA, Bardon CG, Carchidi PJ, Kittler AF, et al. A cost-benefit analysis of electronic medical records in primary care. Am J Med 2003;114(5):397-403.

15. Featherly K, Garets D, Davis M, Wise P, Becker P. Sharpening the Case for Returns on Investment from Clinical Information Systems. Electronic Healthcare 2006;5(3):101-10.

16. Meyer R, Degoulet P, Omnes L. Impact of Health Care Information Technology on Hospital Productivity Growth: a Survey in 17 Acute University Hospitals. Medinfo 2007;12(1):203-7.

17. Ransom SB, Joshi MS, Nash DB. The Healthcare quality book: vision, strategy and tools. Chicago: Health Administration Press; 2004.

18. Tan J. e-Healthcare Information Systems: An Introduction for Students and Professionals. San Francisco: Jossey-Bass; 2005.

19. [Online] March 2008. http://en.wikipedia.org/wiki/ Return_on_investment.

20. Kaushal R, Jha AK, Franz C, Glaser J, Shetty KD.
Return on investment for a computerized physician order entry system. J Am Med Inform Assoc 2006 May-Jun;13(3):365-7.

21. Anthes G. http://www.computerworld.com/ special_report $/ 000 / 000 / 100 /$ special_report_000000180_primary_article.jsp. [Online]

22. McLean RA. Cost-volume-profit and net present value analysis of health information systems. Top Health Inf Manag 1998;19(1):39-47.

23. Kaplan JG. The net present value of investments in health. Med Interface 1996;9(11):94-6.

24. Rendina MC. A net present value analysis of neonatal telecardiology. Telemed Today 2000;8(2):23-5.

25. Boles K, Fleming S. Breakeven under capitation: pure and simple? Health Care 1996;21(1):38-47.

26. Gapenski, LC. Accuracy of investment risk models varies. Healthc Financ Manag 1992;46(4):40-4.

27. Gapenski C. Healthcare Finance: an introduction to accounting and financial management. Chicago: Health Administration Press; 2005.

28. Saltelli A, Ratto M, Andres T, Campolongo F. Global Sensitivity Analysis. The Primer. Hoboken: John Wiley \& Sons, 2007.

29. Meltzer MI. Introduction to health economics for physicians. The Lancet 2001,358:993-8.

30. Palmer AJ, Annemans L, Roze S, Lamotte M, Lapuerta P, Chen R, et al. Cost-effectiveness of early irbesartan treatment versus control or late irbesartan treatment in patients with type 2 diabetes, hypertension, and renal disease. Diabetes Care 2004;27(8):1897-903.

31. Holmes RL, Schroeder RE, Harrington LF. Objective Risk Adjustment Improves Calculated ROI For Capital Projects. Healthcare Financial Management 2000(12).

32. McGrath R, Ferrier WJ, Mendelow AL. Real Options as Engines ofChoice and Heterogeneity. Academy of Management Review 2004:29(1):86-101.

33. McGrath R and Nerkar A. Real Options Reasoning and a New Look at the R\&D Investment Strategies of Pharmaceutical Firms." 25: 1-21. Strategic Management Journal 2004;25:1-21.

34. Williams DR, Walker JA, Hammes PH. Real options reasoning in healthcare: an integrative approach and synopsis. J Healthc Manag 2007;52(3):170-86.

35. Menachemi N, Burkhardt J, Shewchuk R, Burke D, Brooks RG. Hospital Information Technology and Positive Financial Performance: A Different Approach to Finding a ROI. J Healthc Manag 2006;51(1).

36. Burke D, Wang B, Wan T, Diana M. Exploring Hospitals' Adoption of Information Technology. Journal of Medical Systems 2002;26(4):349-55.

37. Poon SK, Davis JG, Choi B. Augmenting productivity analysis with data mining: An application on IT business value. Expert Systems with Applications. doi:10.1016/j.eswa.2007.12.028, 2008.

38. [Online] March 2008. http://www.ssco.com/.

39. [Online] March 2008. http:// www.thehackettgroup.com/.

40. [Online] March 2008. http:// www.thepalladiumgroup.com/.

41. [Online] March 2008. http://www.the-betagroup.com/.

42. [Online] March 2008. http://www.itpmg.com/

43. [Online] March 2008. http://www.forrester.com/rb/ 
research

44. [Online] March 2008. http://www.gartner.com/.

45. Hoffman T. [Online] March 2008. http:// www.computerworld.com/managementtopics/roi/ story/0,10801,78541,00.html.

46. Ulfelder S. [Online] March 2008. http:// www.computerworld.com/special_report/000/000/ 100/special_report_000000180_primary_article.jsp.

47. Christensen CM, Kaufman SP, Shih WC. Innovation Killers: How Financial Tools Destroy Your Capacity to Do New Things. Harvard Business Review 2008;86(1):98-105.

48. Greene W. Econometric Analysis. Upper Saddle river, New Jersey: Pearson Education Inc.;2003.

49. Gujarati D. Basic Econometrics. Columbus: McGraw-Hill Higher Education; 2003.

50. Brinkerhoff RO, Dressler DE. Productivity measurement: a guide for managers and evaluators. Newbury Park (Calif.): Sage; 1990. p. 16.

51. Baier SL, Dwyer GP, Tamura R. How Important Are Capital and Total Factor Productivity for Economic Growth? Federal Reserve Bank of Atlanta Working Paper No. -. 2005, Vol. 2002, 02.

52. Barro RJ. Notes on Growth Accounting. National Bureau of Economic Research. 1998, Vol. Working Paper No. W6654.

53. Romer PM. The Origins of Endogenous Growth. Journal of Economic Perspectives 1994(8)1:3-22.

54. Cobb CW, Douglas PH. A Theory of Production. American Economic Review 1928;18(1):139-65.

55. Solow RM. A Contribution to the Theory of Economic Growth. The Quarterly Journal of Economics 1956;1 LXX:65-94.

56. Hitt LM, Brynjolfsson E. Productivity, business profit-ability, and consumer surplus: three differentf measures of information technology value. MIS Quarterly 1996;20(2):121-42.

57. Stadelmann D. Fonction de production - illustration des propriétés pour l'analyse économique. Fribourg: Séminaire de l'université de Fribourg, 2003-2004.

58. Alpar P, Kim M. A Comparison of Approaches to the Measurement of IT Value. In: Proceedings of the Twenty-Second Hawaii International Conference on System Science; 1990.

59. Brynjolfsson E, Hitt LM. Paradox lost: Firm level evidence on returns to information systems spending. Management Science. 1996;42:541-58.

60 . Weill P. The relationship between investment in information technology and firm performance : a study of the valve manufacturing sector. Information Systems Research 1992;3(4):307-33.

61. Siegel D, Griliches Z. Purchased services, outsourcing, computers, and productivity in manufacturing. In: Z. Griliches, Editor, Output measurement in the service sector. Chicago: University of Chicago Press; 1992. p. 429-58.

62. Mahmood M, Mann GJ. Measuring the organizational impact of information technology investment: an exploratory study. Journal of Management Information Systems 1993;10(1):97-122.

63. Siegel D. The impact of computers on manufacturing productivity growth: A multiple-indicators, multiple-causes approach. The Review of Economics and Statistics 1997;79:68-78.

64. Lichtenberg F. The output contributions of computer equipment and personnel: a firm-level analysis. Journal of Economic Innovation and New Tech- nologies 1995;3(4):201-17.

65. Loveman GW. An assessment of the productivity impact of information technologies. In: Allen TJ, Scott Morton MS, editors. Information Technology and the Corporation of the 1990s: Research Studies. Oxford: Oxford University Press; 1994. p. 84-110.

66. Greenan N, Mairesse J. Computers and productivity in France: Some evidence. NBER Working Paper No. 5836. 1996, Vol. November.

67. Lehr W, Lichtenberg FR. Computer use and productivity growth in US federal government agencies, 1987-92. Journal of Industrial Economics 1998;46:257-79.

68. McGuckin RH, Streitwieser ML, Doms M. The effect of technology use on productivity growth. Economics of Innovation and New Technology. 1998;7:1-27.

69. McGuckin RH, Stiroh KJ. Computers and productivity: Are aggregation effects Important? Economic Inquiry 2002;40(1):42-59.

70. Gera S, Gu W, Lee F. Information technology and labour productivity growth: An empirical analysis for Canada and the United States. Canadian Journal of Economics 1999;32:384-407.

71. Jorgenson DW, Stiroh KJ. Raising the speed limit: US economic growth in the information age. Brookings Papers on Economics Activity 2000 , Vol. 1. p. 125-211.

72. Barua, A, Kriebel, C and Mukhopadhyay, T. Information Technology and Business Value: An Analytic and Empirical Investigation. University of Texas at Austin Working Paper. May, 1991.

73. Berndt ER, Morrison CJ. High-Tech Capital Formation and Economic Performance in U.S. Manufacturing Industries: An Exploratory Analysis. Journal of Econometrics 1995;65(1):9-43.

74. Morrison CJ, Berndt ER. Assessing the Productivity of Information Technology Equipment in the U.S. Manufacturing Industries. National Bureau of Economic Research Working Paper;1990, Vol. 3582.

75. Pilat D. The ICT productivity paradox: insights from micro data. OECD Economic Studies. 2004, Vol. 38, pp. 37-65.

76. Attewell P. Organizational Linkages: Understanding the Productivity Paradox. Washington: National Academic Press; 1994. p. 13-53.

77. Marakas GM, Robey D. managing impressions with information technologies. Proceedings of the 1994 computer personnel research conference on Reinventing IS: managing information technology in changing organizations;1994. p. 15-22.

78. Ross A, Ernstberger K. Benchmarking the IT productivity paradox: recent evidence from the manufacturing sector. Mathematical and Computer Modelling; 2006, Vol. 44. p. 30-42.

79. Brynjolfsson, E. The productivity paradox of IT. Communication of the ACM December1993;36(12).

80. Prasad B, Harker P. Examining the contribution of information technology toward productivity and profitability in US retail banking. Working paper no. 97-09, Financial Institutions Center, The Wharton School; 1997.

81. Lin WT, Shao BM. The business value of information technology and inputs substitution: the productivity paradox revisited. Decision support systems. 2006, Vol. 42. p. 493-507.

82. Dewan S, Min CK. The substitution of informa- tion technology for other factors of production : a firm level analysis. Management Science. 1997, Vol. 43(12):1660-75.

83. Lee B, Menon N. Information technology value through different normative lenses. Journal of Management Information Systems 2000;16(4):99-119.

84. Bharadwaj A. A resource-based perspective on information technology capability and firm performance : an empirical investigation. MIS Quarterly. 2000;24(1):169-96

85. Stratopoulos T, Dehning B. Does successful investment in information technology solves the productivity paradox ? Information and Management 2000;38:103-17.

86. Shao BM. Investigating the value of information technology in productive efficiency: an analytic and empirical study. [Ph.D. dissertation]. State University of New York, Buffalo; 2000.

87. Shao BM, Lin WT. Technical efficiency analysis of information technology investments: a two-stage empirical investigation. Information and Management 2002;39:391-401.

88. Shao BM, Lin WT. Examining the determinants of productive efficiency with IT as a production factor. Journal of Computer Information Systems 2000;41(1):25-30.

89. Shao BM, Lin WT. Measuring the value of information technology in technical efficiency with stochastic production frontiers. Information and Software Technology 2001;43:447-56.

90. Osei-Brison KM, Ko M. Exploring the relationship between information technology investments and firm performance using regression splines analysis. Information \& Management 2004:42:1-13.

91. Koc C. The productivity of health care and health production functions. Health Econ 2004;13(8):739-47.

92. Hollingsworth B, Dawson PJ, Maniadakis N. Efficiency measurement of health care: a review of nonparametric methods and applications. Health Care Manag Sci 1999;2(3):161-72.

93. Grosskopf S, Valdmanis V. Measuring Hospital performance: a non-parametric approach. Journal of Health Economics 1987;6:87-109.

94. Menon N, Lee B, Eldenburg L. Productivity of Information Systems in the Healthcare Industry. Information Systems Research 2000;11(1):83-92.

95. Lovell CAK. Production frontiers and production efficiency in The Measurement of Productive Efficiency: Techniques and Applications. New-York: Oxford University Press; 1993.

96. Eubank R. Spline Smoothing and Nonparametric Regression, Marcel. New York: Marcel Dekker Inc; 1987.

97. Hitt, LM and Snir, EM. The role of information technology in modern production: complement or substitute to other inputs? University of pennsylvania papers; January 1999.

98. Lin WT, Shao BM. Relative sizes of information technology investments and productive efficiency: Their linkage and empirical evidence. Journal of the Association for Information Systems 2000;1(7):1-35

99. Bresnahan TF, Brynjolfsson E, Hitt LM. Information technology, Workplace Organization, and the demand for skilled labor: Firm-level evidence. The Quarterly Journal of Economics 2002;117(1):339-76.

100. Beard N, Elo K, Hitt LM, Housman MG, 
Mansfield G. Information technology and hospital performance: An econometric analysis of costs and quality. [Online] PricewaterhouseCoopers: http://www.pwc.com/healthcare, 2007.

101. Holland M. Perspective on the value of HIT investment. Health Industry Insights. [Online] http:/ /www.healthindustry-insights.com/HII/ getdoc.jsp? containerId=HI206330.

102. Schulman J, Kuperman GJ, Kharbanda A, Kaushal R. Discovering How to Think about a Hospital Patient Information System by Struggling to Evaluate It: A Committee's Journal. J Am Med Inform Assoc 2006; 14:537-41.

103. Philips Z, Ginnelly L, Sculpher M, Claxton K, Golder S, Riemsma R, et al. Review of guidelines for good practice in decision-analytic modelling in health technology assessment. Health Technology Assessment 2004;8(36).

104. Brynjolfsson, E. The IT Productivity GAP. Optimize 2003;21.

105. Bleom J, VanDoorn M, Mittal P. Making IT governance work in a Sarbanes-Oxley world. Oboken: Willey \& Sons Inc; 2006. p. 46-90, 153-7.

106. Hoogeveen D, Oppelland HJ. A socio political model of the relationship between IT investments and business performance. Proceedings of the 35 th Hawaii International Conference on Systems Sciences; 2002 .
107. Li R, Ye LR. Information technology and firm performance: linking with environmental, strategic and managerial contexts. Information and Management 1999;35:43-51.

108. Teo TSH, Wong PK, Chia EH. Information Technology (IT) investment and the role of a firm: an exploratory study. International Journal of Information Management 2000;20:269-86.

109. Soh C, Markus ML. How IT creates business value: a process theory synthesis. Proceedings of the 16th International Conference on Information Systems, Amsterdam; 1995. p. 29-41.

110. Soh C, Markus ML. Banking on information technology: converting IT spending into firm performance. [book auth.] R Banker, R Kaufmann and M Mahmood. Strategic Information Technology Management: Perspectives on Organizational Growth and Competitive Advantage. Hershey: Idea Group Inc. Publishing; 1993. p. 375-404.

111. Kumbhakar SC, Tsionas EG. Estimation of stochastic frontier production functions with inputoriented technical efficiency. Journal of Econometrics 2006;133:71-96.

112. Barua A, Mukhopadhyay T. Information technologies and business performance: past, present, and future. [book auth.] Zmud R. Framing the Domains of IT Management Projecting the Fu- ture through the Past. Cincinnati: Pinnaflex Education Resources, Inc; 2000.

113. Maynard A, Kanavos P. Health economics: an evolving paradigm. Health Econ 2000;9:183-90.

114. Kivijarvi H, Saarinen T. Investment in information systems and the financial performance of the firm. Information and Management 1995;28:143-63.

115. Stiroh K. Reassessing the Impact of IT in the Production Function. New York: Federal Reserve Bank of New York; 2002.

\section{Correspondence to:}

Dr Rodolphe Meyer, MD, MPh

University Hospitals of Geneva, Service of Medical Informatics

24, rue Micheli-Du-rest

CH-1211 Geneval4

E-mail: rodolphe.meyer@sim.hcuge.ch

Pr Patrice Degoulet, MD, PhD

Département d"Informatique Hospitalière - HEGP

20, rue Leblanc

75015 Paris - France

E-mail: patrice.degoulet@egp.aphp.fr 


\section{Annex: Econometric studies on IT (Health care sector studies in darker gray)}

\begin{tabular}{|c|c|c|c|c|c|}
\hline Year & Authors & Methodology & Data & Measures & Results \\
\hline 1992 & P Weill [60] & Hierarchical Regression Analysis & 33 firms from 1982 to 1987 & $\begin{array}{c}\text { IT investments and financial data (sells, } \\
\text { productivity, ROA) }\end{array}$ & $\begin{array}{c}\text { No evidence of IT positive impact on } \\
\text { strategy }\end{array}$ \\
\hline 1992 & $\begin{array}{l}\text { D Siegel and Z } \\
\text { Griliches [61] }\end{array}$ & $\begin{array}{l}\text { Correlation research between IT } \\
\text { investment and productivity factors }\end{array}$ & $\begin{array}{l}\text { USA \& Canada industries } \\
\text { macroeconomic data in } 1992\end{array}$ & Capital IT, labor & $\begin{array}{l}\text { Positive link between IT investments and } \\
\text { labor productivity }\end{array}$ \\
\hline 1993 & $\begin{array}{l}\text { M Mahmood and GJ } \\
\text { Mann [62] }\end{array}$ & $\begin{array}{l}\text { Pearsonian correlation and } \\
\text { canonical correlation }\end{array}$ & $\begin{array}{c}100 \text { firms listed in the Computerworld } \\
\text { magazine in } 1989\end{array}$ & IT investments and economical measures & Low level IT impact \\
\hline 1994 & GW Loveman [65] & $\begin{array}{l}\text { Production function and } \\
\text { regression analysis }\end{array}$ & 60 firms from 1978 to 1984 & IT expenses, IT capital and IT labor & No proofs of increased earnings with IT \\
\hline 1995 & $\begin{array}{l}\text { H Kivijarvi and T } \\
\text { Saarinen [114] }\end{array}$ & Variance analysis & 36 firms from Finland & $\begin{array}{l}\text { IT Investments, financial performances, user } \\
\text { satisfaction }\end{array}$ & $\begin{array}{c}\text { No obvious direct relation of yearns with } \\
\text { IT }\end{array}$ \\
\hline 1995 & F Lichtenberg [64] & Regression analysis & $\begin{array}{l}\text { Firms listed in the Computer world and } \\
\text { Information Weekmagazines from } 1988 \text { to } 1991\end{array}$ & $\begin{array}{c}\text { IT investments, IT capital, global capital IT } \\
\text { labor and global labor }\end{array}$ & $\begin{array}{l}\text { Direct influence of It capital and IT labor on } \\
\text { incomes }\end{array}$ \\
\hline 1996 & $\begin{array}{l}N \text { Greenan and J } \\
\text { Mairesse [66] }\end{array}$ & Cobb-Douglas & $\begin{array}{c}\text { Economical data from industry and service in } \\
1987,1991 \text { et } 1993\end{array}$ & Productivity, capital, salaries & $\begin{array}{l}\text { Higher IT impact in services than in } \\
\text { industry }\end{array}$ \\
\hline 1996 & $\begin{array}{l}\text { LM Hitt and E } \\
\text { Bryniolfsson [56] }\end{array}$ & Cobb-Douglas & 370 US firms from 1988 to 1992 & Productivity, profits,value & Higher productivity linked to IT \\
\hline 1997 & D Siegel [63] & Regression analysis & USA industry from 1974 to 1994 & Productivity, capital, salaries & $\begin{array}{l}\text { Positive statistical impact of IT } \\
\text { investments }\end{array}$ \\
\hline 1997 & $\begin{array}{l}\text { B Prasad and } \\
\text { P Harker [80] }\end{array}$ & Cobb-Douglas & 115 banks from 1993 to 1995 & \begin{tabular}{|c|} 
IT capital, non IT capital, IT labor, non IT \\
labor
\end{tabular} & $\begin{array}{l}\text { Higher productivity linked to IT } \\
\text { labor }\end{array}$ \\
\hline 1997 & $\begin{array}{l}\text { S Dewan and CK Min } \\
{[82]}\end{array}$ & \begin{tabular}{|c|}
$\begin{array}{c}\text { Constant elasticity of substitution, } \\
\text { production function, translog function }\end{array}$ \\
\end{tabular} & 370 US firms from 1988 to 1992 & Capital IT, global capital, labor, productivity & $\begin{array}{c}\text { IT capital is linked to global capital and } \\
\text { labor in productivity results }\end{array}$ \\
\hline 1998 & $\begin{array}{l}\text { W Lehr and FR } \\
\text { Lichtenberg [67] }\end{array}$ & Cobb-Douglas & $\begin{array}{c}\text { Government agencies in the USA from } 1987 \\
\text { to } 1992\end{array}$ & IT capital et labor & High IT ROI with measures done \\
\hline 1998 & $\begin{array}{l}\text { RH McGuckin, ML Streit- } \\
\text { wieser and M Doms [68] }\end{array}$ & Cobb-Douglas & USA industry from 1988 to 1993 & Capital, labor, technological level & $\begin{array}{l}\text { Higher productivity of firms using } \\
\text { computer }\end{array}$ \\
\hline 1999 & $\begin{array}{l}\text { RH McGuckin and KJ } \\
\text { Stiroh [69] }\end{array}$ & Cobb-Douglas & $\begin{array}{c}\text { US firms data from the BEA (Bureau of } \\
\text { Economic Analysis) }\end{array}$ & II capital, global capital, labor, productivity & Global productivity profits \\
\hline 1999 & $\begin{array}{c}\text { S Gera, W Gu and F Lee } \\
{[70]}\end{array}$ & Cobb-Douglas & \begin{tabular}{c|l|} 
Industry in Canada \& USA from 1971 to \\
1993
\end{tabular} & IT capital, global capital, labor, productivity & $\begin{array}{l}\text { Positive relationship between IT } \\
\text { investments and labor productivity }\end{array}$ \\
\hline 2000 & $\begin{array}{l}\text { DW Jorgenson and } \mathrm{KJ} \\
\text { Stiroh [71] }\end{array}$ & $\begin{array}{l}\text { Cobb-Douglas and translog } \\
\text { function }\end{array}$ & All industries in the USA from 1959 to 1998 & IT capital, global capital, labor, incomes & $\begin{array}{l}\text { Noticeable positive impact of IT on } \\
\text { productivity after } 1990\end{array}$ \\
\hline 2000 & A Bharadwai [84] & $\begin{array}{c}\text { Logistic regression and Wilcoxon } \\
\text { rank sum test }\end{array}$ & $\begin{array}{l}56 \text { firms listed in Information Week } \\
\text { magazine from } 1991 \text { to } 1994\end{array}$ & Costs and profits measures & $\begin{array}{l}\text { Positive relationship between IT } \\
\text { investments and productivity }\end{array}$ \\
\hline 2000 & B Lee and N Menon [83] & ] Variance and cluster analysis & 1064 firms from 1976 to 1994 & $\begin{array}{l}\text { IT capital, non IT capital, IT labor, non IT } \\
\text { labor }\end{array}$ & $\begin{array}{c}\text { Positive relationship between IT } \\
\text { investments and productivity but negative } \\
\text { relationship between IT labor and } \\
\text { productivity }\end{array}$ \\
\hline 2000 & $\begin{array}{l}\text { TStratopoulos and } \\
\text { B Dehning [85] }\end{array}$ & Wilcoxon test & 71 firms from 1988 to 1997 & Financial performances & $\begin{array}{l}\text { Successful IT investments give higher } \\
\text { financial results }\end{array}$ \\
\hline 2000 & $\begin{array}{c}\text { N Menon, B Lee and L } \\
\text { Eldenburg [94] }\end{array}$ & Stochastic frontier & US hospitals data from 1976 to 1994 & $\begin{array}{l}\text { medical IT capital, medical capital, IT } \\
\text { capital, medical labor and IT labor }\end{array}$ & Positive impact of IT in outputs \\
\hline $2000-$ & $\begin{array}{l}\text { B Shao and W Lin } \\
\text { [88][89] [87] }\end{array}$ & $\begin{array}{l}\text { Cobb-Douglas and translog } \\
\text { function }\end{array}$ & 370 US firms from 1988 to 1992 & Capital, labor, IT investments & $\begin{array}{l}\text { Positive impact of IT investments on } \\
\text { technical efficiency and productivity }\end{array}$ \\
\hline 2002 & Stiroh K [115] & Meta Analysis & $\begin{array}{l}\text { US firms data from the BEA (Bureau of } \\
\text { Economic Analysis) }\end{array}$ & IT elasticity & Positive impact of IT \\
\hline 2004 & $\begin{array}{l}\text { KM Osei- Bryson and } \\
M \text { Ko }[90]\end{array}$ & MARS & US hospitals data from 1976 to 1994 & Capital, labor, IT investments & Positive impact of IT investments \\
\hline 2006 & \begin{tabular}{|c|} 
R Meyer and P Degoulet \\
{$[16]$}
\end{tabular} & $\begin{array}{l}\text { Extended Cobb-Douglas } \\
\text { production function }\end{array}$ & 17 not for profit hospitals & Capital, Labor, IT capital and IT labor & $\begin{array}{c}\text { Positive impact of IT, increased impact } \\
\text { over time, higher impact in integrated } \\
\text { HIS }\end{array}$ \\
\hline 2007 & $\operatorname{PwC}[100]$ & Global econometric analysis & 2000 US hospitals & Capital, Labor, IT capital & $\begin{array}{l}\text { Positive impact of IT, increased impact } \\
\text { over time, IT improves quality }\end{array}$ \\
\hline
\end{tabular}

